J. Clin. Chem. Clin. Biochem.

Vol. 14, 1976, pp. 155-158

\title{
A Kinetic Method for Serum 5' -Nucleotidase Using Stabilised Glutamate Dehydrogenase
}

\author{
By C. L. M. Arkesteijn
}

Biochemistry Laboratory, Diaconessenhuis, Leiden, The Netherlands

(Received March 3/August 1, 1975)

Summary: A modification of a kinetic determination of 5'-nucleotidase (EC 3.1.3.5) activity is described. Special attention has been paid to the stabilisation of glutamate dehydrogenase (EC 1.4.1.2) by $L$-leucine, optimal NADH concentration and the influence of endogeneous ammonia. The optimal concentrations of the other constituents of the reagent were checked with the optimal values given in the literature. Normal values were determined. The proposed method shows a good correlation with a colorimetric reference method.

\section{Ein kinetisches Verfahren zur Bestimmung von 5'-Nucleotidase im Serum unter Verwendung stabilisierter Glutamat- dehydrogenase}

Zusammenfassung: Die Modifikation einer kinetischen Bestimmung von 5'-Nucleotidase (EC 3.1.3.5) wird beschrieben. Besonders wurde auf die Stabilisierung der Glutamatdehydrogenase (EC 1.4.1.2) durch $L$-Leucin, optimale NADHKonzentration und den Einfluß von endogenem Ammoniak geachtet. Die optimalen Konzentrationen der übrigen Bestandteile des Reagenz wurden mit den in der Literatur angegebenen optimalen Werten überprüft. Die vorgeschlagene Methode zeigt eine gute Korrelation mit einer kolorimetrischen Bezugsmethode.

\section{Introduction}

Recently, kinetic methods for the determination of $5^{\prime}$-nucleotidase have been described using bovine glutamate dehydrogenase in a coupled assay $(1,2)$. Briefly, adenosine liberated by the action of $5^{\prime}$-nucleotidase is converted to inosine and ammonia with adenosine deaminase (EC 3.5.4.4). In a coupled reaction catalysed by glutamate dehydrogenase ammonia forms glutamate in the presence of 2-oxoglutarate and $\mathrm{NADH}$. The overall reaction is monitored by the decrease in extinction at $340 \mathrm{~nm}$ caused by conversion of $\mathrm{NADH}$ to NAD. A fairly high concentration of NADH is required to compensate for side reactions such as removal of endogeneous ammonia and pyruvic acid during a pre-incubation period. NADH however, will inactivate glutamate dehydrogenase especially at higher concentrations (3). The inactivation promoted by NAD can be abolished by adding allosteric modifiers such as $\operatorname{ADP}(3,4,5)$ or $L$-leucine $(6,7)$. Preliminary experiments revealed that $L$ leucine, unlike ADP (1), does not affect the measurement of $5^{\prime}$-nucleotidase activity (Persijn, personal communication). The present report describes a kinetic assay with glutamate dehydrogenase protected against inactivation under conditions optimal for the measurement of $5^{\prime}$-nucleotidase activity.

\section{Materials and Methods}

\section{Materials and Methods}

The enzyme reaction rates were measured at $340 \mathrm{~nm}$ on a Photovolt Era I reaction rate analyzer at $37^{\circ} \mathrm{C}$. The following solutions were prepared:

Solution 1: Dissolve in $900 \mathrm{ml}$ aqua dest. $17.28 \mathrm{~g}$ triethanolamine/ $\mathrm{HCl}(0.115 \mathrm{~mol} / \mathrm{l}), 3.02 \mathrm{~g} \mathrm{~L}$-leucine $(23 \mathrm{mmol} / \mathrm{l}), 847 \mathrm{mg} \mathrm{Na}-2-$ oxoglutarate $(5.75 \mathrm{mmol} / \mathrm{l})$ and $12.53 \mathrm{~g} \mathrm{Na}-\beta$-glycerophosphate $(57.5 \mathrm{mmol} / \mathrm{l})$. Adjust to $\mathrm{pH} 7.6$, add $259 \mathrm{mg} \mathrm{MnSO} 4 \cdot 2 \mathrm{H}_{2} \mathrm{O}$ $(1.15 \mathrm{mmol} / \mathrm{l})$ and dilute to $1000 \mathrm{ml}$.

Stable for 2 weeks at $4^{\circ} \mathrm{C}$.

Solution 2: Dissolve $144 \mathrm{mg} \mathrm{NADH}(40 \mathrm{mmol} / \mathrm{l})$ in $5 \mathrm{ml}$ aqua dest. Stable for 1 week at $4{ }^{\circ} \mathrm{C}$.

Solution 3: Adenosine deaminase in glycerol, $400 \mathrm{kU} / \mathrm{l}$, Boehringer 15069 EAAT.

Solution 4: Glutamate dehydrogenase in glycerol, $900 \mathrm{kU} / \mathrm{l}$, Boehringer 15324 EGAH.

Solution 5: Dissolve $10 \mathrm{mg} \mathrm{5'-AMP} \mathrm{(23} \mathrm{mmol/1)} \mathrm{in} 1 \mathrm{ml}$ water. Prepare fresh daily.

Working solution: Prior to use, mix solutions 1, 2, 3 and 4 in the ratio $10 \mathrm{ml}+0.1 \mathrm{ml}+0.01 \mathrm{ml}+0.1 \mathrm{ml}$. Stable for $4 \mathrm{hr}$ at room temperature. The final concentrations in the cuvet are according the selected values of table 1 .

\section{Procedure}

Pipet $0.2 \mathrm{ml}$ of fresh serum in to a test tube and add $2 \mathrm{ml}$ working solution, $\mathrm{mix}$ and incubate the tube for $30 \mathrm{~min}$ in a waterbath at $37^{\circ} \mathrm{C}$. Add then $0.1 \mathrm{ml}$ of solution 5 and mix. Measure the $\Delta \mathrm{E} / \mathrm{min}$ after $2 \mathrm{~min}$ temperature equilibration. 
Tab. 1. Optimal concentrations of reagents in the cuvet.

\begin{tabular}{lll}
\hline Reagent & Range & Selected \\
\hline$L$-leucine & $20-30 \mathrm{mmol} / 1$ & $20 \mathrm{mmol} / 1$ \\
NADH & $0.15-0.45 \mathrm{mmol} / 1$ & $0.35 \mathrm{mmol} / 1$ \\
2-oxoglutarate & $3-10 \mathrm{mmol} / 1$ & $5 \mathrm{mmol} / 1$ \\
$S^{\prime}$-AMP & $0.75-3 \mathrm{mmol} / 1$ & $1 \mathrm{mmol} / 1$ \\
Glutamate dehydrogenase & $5-13 \mathrm{kU} / 1$ & $9 \mathrm{kU} / 1$ \\
adenosine deaminase & $0.1-0.5 \mathrm{kU} / 1$ & $0.4 \mathrm{kU} / 1$ \\
tricthanolamine/HCl & not studied & $100 \mathrm{mmol} / 1$ \\
$\beta$-glycerophosphate & not studied & $50 \mathrm{mmol} / 1$ \\
$\mathrm{Mn}^{+}$ & not studied & $1 \mathrm{mmol} / 1$ \\
\hline
\end{tabular}

To obtain the activity in $\mathrm{U} / \mathrm{l}$, multiply the $\Delta \mathrm{E} / \mathrm{min}$ by the factor 1850 . This factor is calculated as follows:

Factor $=\frac{1000 \times V_{t}}{\epsilon \times V_{s}} V_{t}=$ total voume, $V_{s}=$ sample volume

and $\epsilon$ is the molar absorption coefficient of NADH at the wave length used $\left(6.22 \mathrm{~cm}^{2} / \mu \mathrm{mol}\right)$.

\section{Results and Discussion}

\section{Optimal $L$-leucine concentration}

To establish the optimal concentration of $L$-leucine for the activity of glutamate dehydrogenase, the following experiment was carried out. Five working solutions were prepared with $L$-leucine concentrations of 5,10 , 15,20 , and $30 \mathrm{mmol} / 1$. Five min after reagent preparation glutamate dehydrogenase activity was measured at $340 \mathrm{~nm}$ after adding $0.07 \mu \mathrm{mol} \mathrm{NH} \mathrm{N}_{4} \mathrm{Cl}$ to $2 \mathrm{ml}$ aliquots of the working solution. According to figure 1 a $L$-leucine concentration of $20 \mathrm{mmol} / \mathrm{l}$ and more is optimal. This result disagrees with the literature where a $L$-leucine concentration of $10 \mathrm{mmol} / 1$ is already optimal $(4,7)$. An explanation of this different result is the high $\mathrm{NADH}$ concentration in the working solution. In the

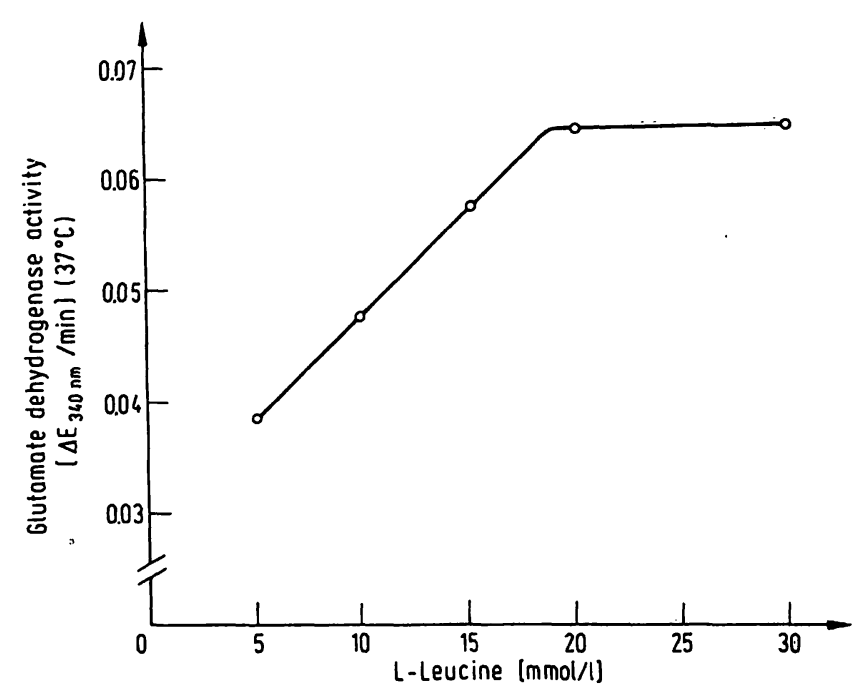

Fig. 1. Effect of different $L$-leucine concentrations on glutamate dehydrogenase activity. proposed method: $0.35 \mathrm{mmol} / 1$, Persijn et al (7):

$0.19 \mathrm{mmol} / 1$, Jung et al (4): $0.25 \mathrm{mmol} / 1$. A $L$-leucine concentration of $20 \mathrm{mmol} / \mathrm{l}$ was chosen in the proposed method and used in further experiments.

\section{Glutamate dehydrogenase stabilisation}

To evaluate the glutamate dehydrogenase stabilising effect of $L$-leucine, and the influence of $\mathrm{Mn}^{+}$, working solutions containing all reagents in their optimal concentration (sol. A), with $\mathrm{Mn}^{+1}(1 \mathrm{mmol} / \mathrm{l})$ and no $L$-leucine (sol. B) and no $L$-leucine and $\mathrm{Mn}^{+1}$ (sol. C) were prepared and allowed to age for $60 \mathrm{~min}$ at $25^{\circ} \mathrm{C}$. Directly following reagent preparation and then at 15 min intervals, glutamate dehydrogenase activity was assayed by adding $0.07 \mu \mathrm{mol} \mathrm{NH} \mathrm{N}_{4} \mathrm{Cl}$ to $2 \mathrm{ml}$ aliquots of the solutions and measuring the decrease in absorption at $340 \mathrm{~nm}$ during the first min. The results shown in figure 2 indicate a rapid inactivation of glutamate dehydrogenase in the absence of $L$-leucine. Although the presence of $\mathrm{Mn}^{\text {t+ }}$ in a concentration of $1 \mathrm{mmol} / 1$ slightly inhibits the glutamate dehydrogenase activity (1), it is necessary for activation of $5^{\prime}$-nucleotidase $(8,9)$. In addition it also has a small stabilising effect on glutamate dehydrogenase. This is in accordance with the findings of Ellis \& Goldberg (1). When the working solutions were aged at $37^{\circ} \mathrm{C}$ essentially the same results were obtained. At this temperature however, sol. A exhibited after $2.5 \mathrm{hr}$ a glutamate dehydrogenase activity of $80 \%$ of the initial value. This has no practical consequences because of the broad optimal range of glutamate dehydrogenase activity (tab. 1). Absence of $\mathrm{Mn}^{+1}$ in solution A in this experiment had no effect on the stability. It is evident that incorporation of $L$-leucine in the working solution contributes considerably to its stability at room and assay temperature.

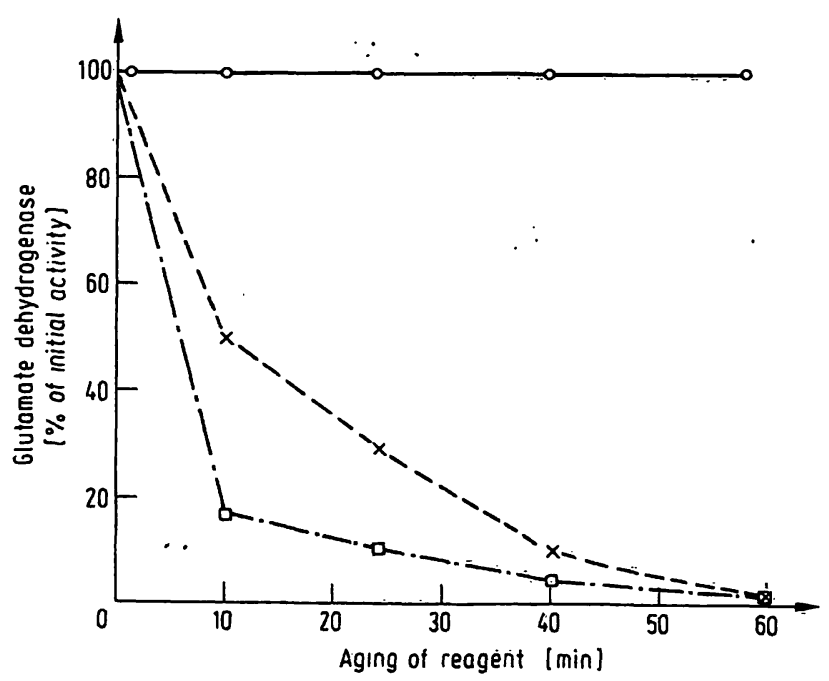

Fig. 2. Effect of $L$-leucine $(20 \mathrm{mmol} / \mathrm{l})$ and $\mathrm{Mn}^{++}(1 \mathrm{mmol} / \mathrm{l})$ on glutamate dehydrogenase stability. Working solutions $\mathbf{A}$, $\mathrm{B}$, and $\mathrm{C}$ contained $L$-leucine and $\mathrm{Mn}^{+}(0-0)$, no $L$-leucine $(\mathrm{x}-\mathrm{x})$ and no $L$-leucine and $\mathrm{Mn}^{+}(\Delta-\Delta)$ resp. 


\section{Optimal NADH concentration and effect of endogeneous ammonia}

Tine optimal NADH concentration in the working solution was established with 3 serum samples with a normal, an elevated and a high $5^{\prime}$-nucleotidase activity resp. The NADH concentration ranged from $0.15-0.45 \mathrm{mmol} / 1$ (fig. 3), the other constituents had the selected values as given in Table 1 . The concentration of $0.35 \mathrm{mmol} / \mathrm{l}$ was chosen for the proposed method to ensure an optimal NADH concentration during the assay, even at high endogeneous ammonia levels and, as a consequence, high NADH consumption during the pre-incubation time. Figure 4 illustrates the decrease in absorbance during a pre-incubation of 3 serum samples with 5 'nucleotidase activities of 25,63 and $125 \mathrm{U} / 1$ resp. The serum sample of $63 \mathrm{U} / \mathrm{l}$ was enriched with ammonia to a concentration of $250 \mu \mathrm{mol} / 1$. After a rapid drop in absorbance, initial decrease in absorbance approaches zero after approximately $25 \mathrm{~min}$ and corresponds to a $5^{\prime}$-nucleotidase activity of less than $0.5 \mathrm{U} / 1$, even in a sample with a high ammonia concentration. The results indicate that a pre-incubation time of $30 \mathrm{~min}$ effectively eliminates side reactions causing non-specific NADH consumption. To demonstrate that after the pre-incubation the NADH concentration is still high enough to carry out the assay, 2 serum samples with different amounts of ammonia were pre-incubated, followed by the determination of the 5 -nucleotidase activity. The results are shown in table 2. It is obvious that ammonia up to a concen-

Tab. 2. Effect of endogeneous ammonia.

\begin{tabular}{lcccc}
\hline $\begin{array}{l}\text { ammonia added } \\
{[\mu \mathrm{mol} / \mathrm{l}]}\end{array}$ & 0 & 50 & 125 & 250 \\
\hline 5'-nucleotidase activity $[\mathrm{U} / \mathrm{l}]$ & & & $\cdot$ \\
sample A & 29 & 30 & 29 & 29 \\
sample B & 63 & 62 & 62 & 59 \\
\hline
\end{tabular}

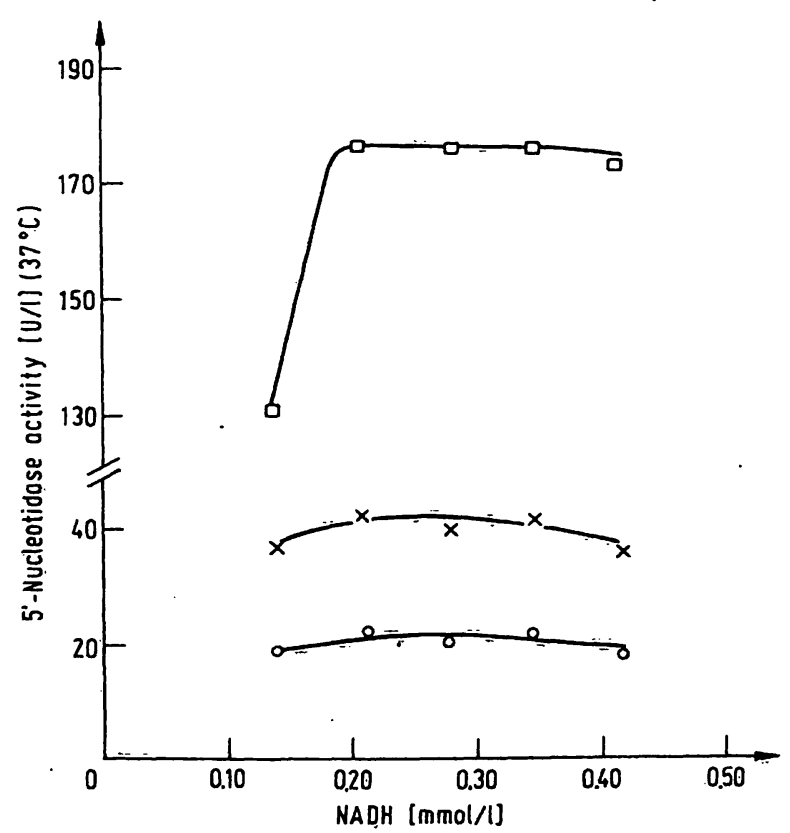

Fig. 3. Optimal $L$-leucine concentration.

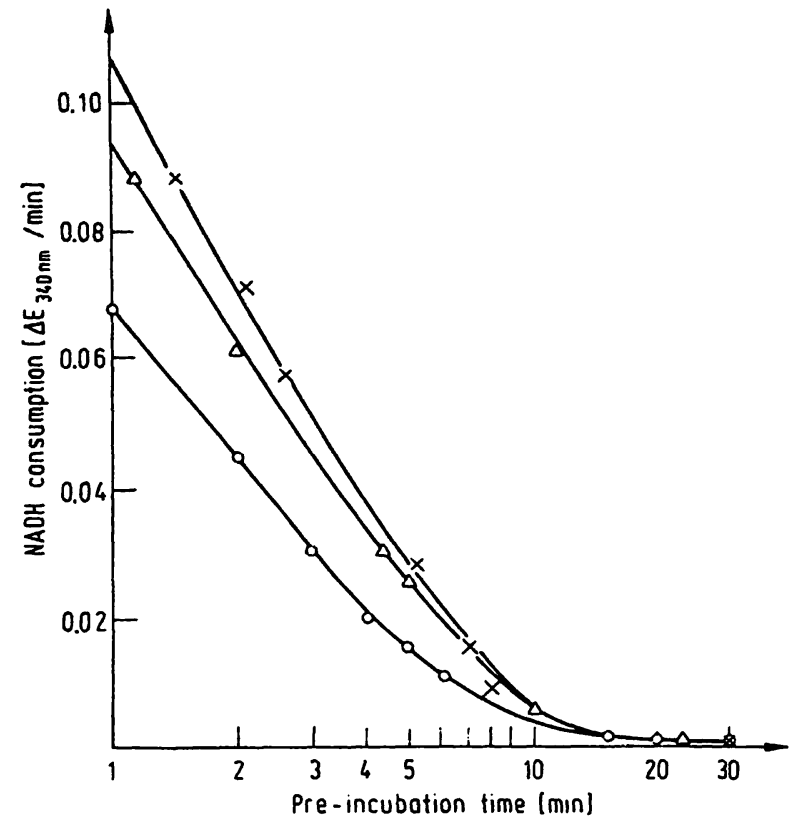

Fig. 4. NADH consumption during pre-incubation. 5 '-nucleotidase activity of serum samples: $154 \mathrm{U} / 1(\mathrm{x}-\mathrm{x})$, $63 \mathrm{U} / 1(\Delta-\Delta)$ and $25 \mathrm{U} / \mathrm{l}(0-0)$. Sample $(\Delta-\Delta)$ contained $250 \mu \mathrm{mol}$ added ammonia.

tration of $250 \mu \mathrm{mol} / 1$ has no effect on the determination of $5^{\prime}$-nucleotidase activity.

\section{Optimal concentrations of reagents}

The optimal concentrations of 2-oxoglutarate, 5 -AMP, glutamate dehydrogenase, adenosine deaminase and the $\mathrm{pH}$ value given in the literature were checked in the proposed method. Experiments with sera having a normal and an elevated $5^{\prime}$-nucleotidase activity resp. revealed that maximal and constant activities were obtained when final reagent concentrations in the reaction mixture were within the ranges shown in table 1 . These ranges are in good agreement with the optimal ranges given in the literature $(1,2,4,7)$. For the additional reagents $\mathrm{Na}-\beta$-glycerophosphate, $\mathrm{Mn}^{++}$and the buffer

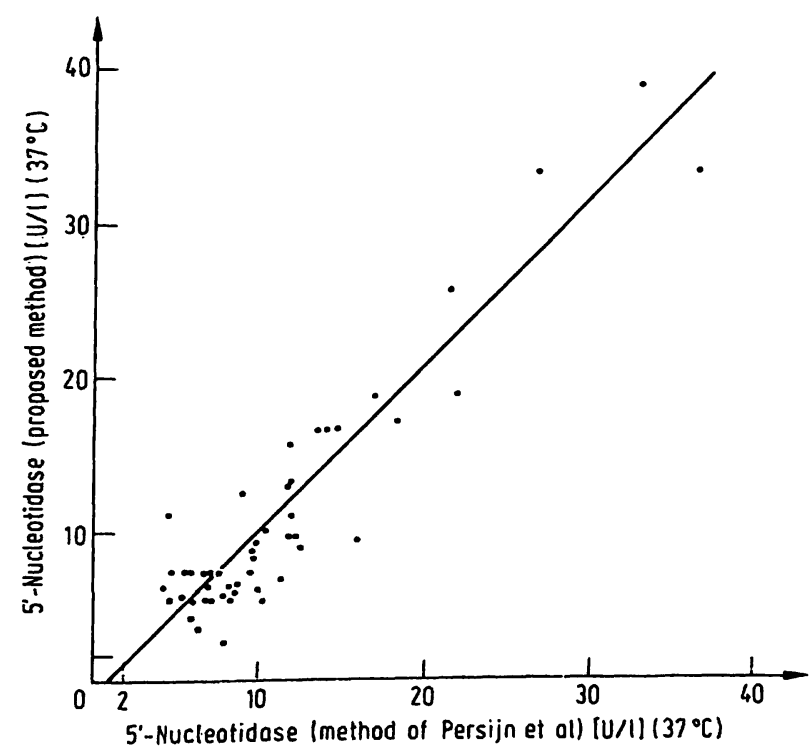

Fig. 5. Comparison of proposed method with reference method. 
composition the recommandations of Ellis \& Goldberg were followed (1). For the routine procedure final concentrations in the cuvet were selected as given in table 1.

\section{Comparison with other method}

This method was compared with the technique of Persijn et al. (10) by parallel analyses of 51 serum samples. The results are plotted in figure 5 . The regression equation $\left(y=1.08 x-0.69, S_{y} \cdot x=4.8\right.$ and the coefficient of correlation is 0.937 ) indicates a good correlation between the two methods.

\section{References}

1. Ellis, G. \& Goldberg, D. M. (1972). Analyt. Lett. 5, 65-73.

2. Bootsma, J. \& Wolthers, B. G. (1972). Clin. Chim. Acta 41, 219-222.

3. Frieden, C. (1959). J. Biol. Chem. 234,-808-814

4. Jung, K., Sokolowski, A. \& Egger, E. (1972/1973). Enzyme 14, 44-54.

5. Ellis, G. \& Goldberg, D. M. (1970). J. Lab. Clin. Med. 76, 505 .

\section{Precision and normal values}

The interrun precision in the normal range was $6.5 \%$ $(\bar{x}=9.8, n=22)$ and in the elevated range $4.9 \%$ $(\bar{x}=23.6, n=22)$. The normal range, compiled from values of 35 healthy persons, was found to be $2.1-10.6$ $\mathrm{U} / 1$ ( $95 \%$ confidence limits).

\section{Acknowledgements}

The auther wishes to express his gratitude to Dr. J.-P. Persijn for his interest and for providing the serum samples for the parallel analyses and to miss $K . H$. Alting and miss $E . C . P$. Videler for their technical assistence.

6. Yielding, K. L. \& Tomkins, G. M. (1961). Proc. Nat. Acad. Sci. 47, 983-989.

7. Persijn, J.-P., Van der Slik, W., Timmer, C. J. \& Riethorst, A. (1970). Clin. Chim. Acta 30, 377-386.

8. Ellis, G. \& Goldberg, D. M. (1970). Spectrovision 23, 8-12.

9. Belfield, A. \& Goldberg, D. M. (1969). J. Clin. Path. 22, 144

10. Persijn, J.-P. \& Van der Slik, W. (1970). Clin. Enzym. 2, $108-112$.

Hofpoort Ziekenhuis Klin. Chem. Lab.

Utrechtsestraatweg 52

Woerden

The Netherlands 